\title{
Climate Adaptation in Swedish Forestry: Exploring the Debate and Policy Process, 1990-2012
}

\section{Johanna Ulmanen ${ }^{1, *}$, Åsa Gerger Swartling ${ }^{2,3}$ and Oskar Wallgren 4}

1 SP Technical Research Institute of Sweden, Eklandagatan 86, Göteborg SE-412 61, Sweden

2 Stockholm Environment Institute, Box 24218, Stockholm SE-104 51, Sweden;

E-Mail: asa.swartling@sei-international.org

3 Stockholm Resilience Centre, Stockholm University, Kräftriket 2 B, Stockholm SE-106 91, Sweden

4 WSP Sverige AB, Arenavägen 7, Stockholm-Globen SE-121 88, Sweden;

E-Mail: oskar.wallgren@wspgroup.se

* Author to whom correspondence should be addressed; E-Mail: Johanna.ulmanen@sp.se; Tel.: +46-010-516-5000.

Academic Editors: Sune Linder and Eric J. Jokela

Received: 17 October 2014 / Accepted: 6 March 2015 / Published: 16 March 2015

\begin{abstract}
This paper explores how climate change adaptation concerns were integrated into the Swedish forestry debate and policy process during the period of 1990-2012, and draws lessons on barriers and opportunities identified in this process. Using a framework focusing on "advocacy coalitions", we analyze how the adaptation debate in the forestry sector evolved over the period; who the main advocates for and against adaptation were; and which main arguments and processes affected the debate and policy. The results show that academics advocating climate change adaptation, aided by outside influences, such as political pressure for adaptation responses and the negative impacts of the 2005 storm Gudrun, contributed to an increased general awareness and understanding of adaptation issues amongst forestry stakeholders. Nonetheless, the strong dominance of actors arguing for increased forest production and the limited number and relatively poor organization of adaptation advocates have acted as barriers to mainstreaming adaptation concerns into forestry policy and practice. The dominant coalitions and their values have also determined the direction of debate and policy. The main conclusions for policymakers aiming to further this integration process are the importance of stimulating adaptation coalitions and the value of creating arenas for multiple stakeholder learning about adaptation.
\end{abstract}


Keywords: climate change adaptation; forestry; forest policy; policy process; Sweden

\section{Introduction}

Over the last decades, climate change adaptation research increasingly has recognised that reducing climate risks requires not only understanding climate change impacts, but also vulnerability and adaptive capacity. The term adaptation as used in this paper refers to "adjustments in ecological, social, or economic systems in response to actual or expected climatic stimuli and their effects or impacts." [1], p. 881. Adaptation, thus, refers to changes in processes, practices, or structures to reduce damages or to take advantage of anticipated opportunities resulting from changes in climate.

Social science has made a number of contributions in adaptation research, addressing the complexity of social, economic, ecological and technical factors shaping climate change vulnerability, adaptation capacity and policy [1-3]. This complexity may be translated into a series of both physical and social barriers to adaptation [4]. In many cases, institutional barriers such as regulations, norms, values and cognitive structures have determined people's responses to climate change [5-8]. These barriers are, however, malleable and may be overcome [4,6]. Some adaptation scholars (see [9] for an overview) focus on ways to remove institutional barriers to foster effective adaptation.

In Scandinavia, scholars have increasingly stressed the need for more analyses of barriers in local or sector-level perspectives, e.g. [10-12]. One such sector is Swedish forestry, a key pillar of the nation's economy. Sweden is the second largest exporter of forest products internationally, and forestry accounts for $10 \%-12 \%$ of Sweden's industrial employment, added value, and exports [13]. Climate change is expected to significantly affect the sector, in terms of increased forest growth, increased forest damage and biodiversity loss [14]. Additionally, scholars [15,16] stress that anticipatory climate adaptation is particularly urgent in the forestry sector due to its long lead times: Forests planted today are likely to be affected by climate change before they are mature for logging in 50-100 years. There is, thus, an obvious need to better understand Swedish forestry's potential vulnerabilities to climate change as well as its potential opportunities, and to adjust forest policy and forestry management practice accordingly.

Adaptation in Swedish forestry is, however, not only a local concern. The Swedish forestry model is presented as combining intensive use and management of the forest for logging purposes with high environmental standards and thorough replanting schemes [17]. It has often been put forward as a forestry model that simultaneously addresses a number of contemporary societal challenges, including climate change and the loss of biodiversity. Thus, the extent to which Swedish forestry manages to incorporate adaptation concerns in policy and practice will be of interest to any other country seeking inspiration from the Swedish forestry development.

Earlier research suggests that Swedish private land owners, who manage some 50\% of Swedish forest lands, have limited belief in climate change effects and the need for adaptation [18] and limited capacity to adapt due to other more pressing socio-economic challenges [19]. Based on these findings, appropriate governance measures are called for [12,18-21].

This paper aims to explore how climate change adaptation concerns were integrated into the Swedish forestry debate and policy in the period of 1990-2012. Theoretically informed hypotheses address the 
evolution of the adaptation debate, its main advocates and critics, and the main events that have influenced the debate over this time period.

We begin by outlining our analytical framework and method, which include a literature review and interviews with a broad set of forestry sector informants. Then we present the results of our research. The subsequent discussion connects the empirical results with the analytical concepts introduced earlier. The paper ends with conclusions concerning how barriers to, and opportunities for, strengthening adaptation in forestry can be addressed.

\section{Approach}

\subsection{Analytical Framework}

Political science offers various perspectives for exploring the policy process see [22,23]. Discourseand network-oriented approaches have proven useful in adaptation research, particularly for analyzing the roles of institutional barriers and how these may be overcome through social innovation [9,10]. Our study applies key concepts from the advocacy coalition framework (ACF) as a means to systematically understand the evolution of the policy process in the context of Swedish forestry. The ACF previously has been used for analyzing forestry-related policy processes, e.g., [24-26]. Within this literature, recent work has applied the ACF to the German forest policy subsystem in order to investigate how discourses on climate change have been merged with long-held ideas about sustainable forest management [27]. This paper contributes to the emerging body of empirical literature that uses ACF concepts to study the integration of climate change concerns in the forestry policy domain.

The ACF framework focuses on learning, in particular scientific and technical learning, as a means for policy change $[22,28,29]$. Its clearly structured, analytical approach highlights socio-economic and institutional factors [30], making it particularly apt for analyzing institutional stability and change [31]. The core idea of ACF, is that multiple actors at various levels of society shape policy through their belief systems: that is, "sets of value priorities and causal assumptions about how to realize them" [32]. The more widely that beliefs are shared, the more they shape policy. At the most pervasive level, deep core beliefs represent stable basic causal and normative beliefs that operate across all policy domains (e.g., free-market principles). At the next level, policy core beliefs represent basic normative commitments of a network: maintaining strong, productive Swedish forests, for example. These beliefs operate across an entire policy domain or subsystem, such as the forestry sector. Finally, secondary aspects are specific to one or several networks but do not operate across an entire subsystem [22,32], such as specific forestry management advice.

Deep core and policy core beliefs shape policies by affecting actors' norms and cognition, integrated in larger systems. Hence, actors will resist information that suggests their deep core and policy core beliefs are wrong or unfeasible, which can make policy change particularly difficult and last over a decade or more [22,32]. The notion of widely shared beliefs correlates with the neo-institutional definition of institutions as relatively stable norms, values, regulative and cognitive structures that steer people's behaviour [33].

Policy change involves the negotiation of beliefs. A network of actors that through coordinated action promotes a particular belief system, an advocacy coalition, emerges out of discontent with incumbent 
policy and the belief system linked to it $[22,32]$. The success of an advocacy coalition is partly related to its ability to strategically influence policy, often in the face of rival coalitions. Coalition strategies relate to the ability to draw on several types of resources, such as influential coalition actors, financial means, public support of coalition beliefs, information supporting coalition beliefs, and skilful coalition leadership, all of which can increase the chance to influence policy [28].

In addition to advocacy coalitions, at least two other key factors promote policy change. The first is policy-oriented learning, which is "relatively enduring alterations of thought or behavioural intentions that result from experience and/or new information and that are concerned with the attainment or revision of policy objectives" [22]. A second factor is events affecting the conditions of the coalitions. These events may be external to a subsystem, such as a change in access to resources, in power structures, or in other subsystem beliefs; or internal, relating to failures within the subsystem [28]. In terms of shaping policy, learning processes are of particular interest, since they can be steered towards specific policy goals, whereas events are often beyond anyone's control.

The most frequent type of policy change is a result of policy-oriented learning that does not challenge policy core beliefs, only secondary aspect beliefs shared within a coalition [22,28]. A related learning concept resulting in such incremental change is "single-loop learning" [34,35]. A policy change challenging policy core beliefs is facilitated either by external events affecting the coalition conditions of a subsystem or by negotiations resulting in cross-coalition learning. This represents a more advanced policy-oriented learning which usually takes place in professional forums [28,32]. A similar concept in the policy learning literature is "double loop learning" [34,35].

Based on the theoretical framework, we present the following hypothesis on the integration of climate change adaptation in the Swedish forestry policy domain:

H1: Policy core beliefs held by key advocacy coalitions in the forestry policy subsystem will hinder the integration of new issues, such as climate change adaptation concerns.

$\mathrm{H} 2$ : The nature of the coalition advocating climate change adaptation, the extent to which coalition actors share beliefs, coordinate action and are able to draw on strategic resources, determine the degree to which climate change adaptation concerns are integrated.

H3: The occurrence of events external and/or internal to the subsystem influence the integration of climate change adaptation concerns.

H4: The types of learning processes taking place determine the extent to which climate change adaptation issues are integrated.

ACF has been criticized for its relatively static view of coalition beliefs, with little room for policy change $[26,36,37]$. We, therefore, pay particular attention to changes in the key coalition beliefs in the forestry sector in our data collection and analysis (see Section 4).

\subsection{Method and Materials}

Our analysis follows a qualitative case study approach [38] to explore the theoretically informed hypotheses outlined above. This exercise leads to a long-term review of the adaptation debate and policy process stretching over a decade, because this is the minimum time for policy change according to the 
ACF [22,32], as well as the identification of key barriers and opportunities for future integration of adaptation issues in the Swedish forestry debate and policy.

Two main types of data have been gathered to identify key actor perspectives across local and national governance levels in the forestry debate and related adaptation issues over time. First, we reviewed various documents, mainly national and local policy documents but also news items and relevant academic literature. Second, in order to confirm and complement the literature data over time, in 2011 we conducted semi-structured interviews with $11 \mathrm{key}$ informants. These informants were involved in forest policy formation at the Swedish Ministry of the Environment, the Swedish Forest Agency, the Federation of Swedish Family Forest Owners (LRF Skogsägarna), Södra (an economic association of forest owners), the Swedish Forest Industries Federation (Skogsindustrierna), the Forestry Research Institute of Sweden (Skogforsk), the Swedish University of Agriculture Sciences (SLU), and WWF Sweden. The interviewees were identified through the literature review and snowball sampling [39]. The interviews were either face-to-face or by phone, one hour on average, of which some were complemented with questions through e-mail or phone. The interviews were transcribed and analyzed together with the written material according to the selected key concepts.

\section{Results}

The results from the empirical analysis of adaptation concerns in Swedish forestry debate and policy are presented in semi-chronological order between 1990 and 2012 with temporal overlaps, following four identified phases of the adaptation and forestry debate. However, we set the stage by introducing the key coalitions that dominate the forestry debate.

\subsection{Key Advocacy Coalitions form in the Forestry Debate}

Previous studies on Swedish forestry [25,26] have defined two key advocacy coalitions - the production coalition and environmental (conservation) coalition-that represent key values in the forestry sector. Similar coalition patterns are common in several countries within and outside Europe [25,27].

In Sweden, the production coalition historically has dominated the forestry sector. This coalition views large-scale rational forestry as a vital national interest, due to "the economic importance of forestry and forest industry" [26], Identified members of the coalition are authorities (Ministry of Industry, Employment and Communication) and forest organizations (Swedish Forest Industries Federation, Swedish Federation of Forest Owners, Swedish Forest, and Wood Trade Union) [26].

In the 1960s, environmental organisations began to challenge the focus on large-scale production, and in the following two decades the environmental conservation coalition emerged to dispute such practices as clear-cutting and extensive pesticide use. [26], see also [40]. Nevertheless, until 1993 production was the only goal of national forestry policy. The 1993 Forestry Act introduced a parallel over-arching goal of protecting biodiversity and environmental quality. Forest owners also were given increased freedom to manage forests, with the government arguing that this would make them more accountable and informed about environmental matters [41,42]. In 1999, the Swedish Parliament agreed on 15 national environmental objectives, with the overall ambition to "solve" all major Swedish environmental problems within one generation, i.e., before 2015-2020 [42,43]. The Swedish Forest 
Agency was given responsibility for only one objective, sustainable forests: "the value of forests and forest land for biological production must be protected, at the same time as biological diversity and cultural heritage and recreational assets are safeguarded" [44].

In particular the biodiversity and environmental quality aspects are in line with the basic value priority "protection of the ecological integrity of forests" that Hysing and Olsson [26], p. 736 assign to the environmentally oriented coalition. The main advocates of the coalition are environmental organisations (WWF Sweden, Greenpeace, Swedish Society for Nature Conservation, and the Swedish Sami Federation), the Swedish Environmental Protection Agency (SEPA), Ministry of the Environment, and the Green Party.

Based on our analysis the above developments were the first of several attempts made in the last two decades to integrate environmental issues with forestry policy [45,46]. Despite these efforts, many argue that the production goal continues to dominate decision-making in Swedish forestry $[25,26,41,42]$ (see interviews).

\subsection{Climate Change Adaptation Viewed as a Non-Issue}

Adaptation issues were largely absent from Swedish national climate change policy in the early 1990 s $[12,47]$. The literature and interviews indicate that this was also true for forestry at the policy level and across the sector in general.

The only significant adaptation-related activity in forestry identified was a new strategy for breeding seedlings introduced by the Forestry Research Institute of Sweden, a foundation largely funded by the Swedish forestry sector. According to Rummukainen et al. [48], the strategy sought to prepare for the future impacts of climate change, to preserve biodiversity, and to improve the general vitality, growth, and wood quality of the trees. An interviewee at the institute said the focus on climate change impacts and vulnerability was pushed by involved climate scientists rather than by the institute itself.

\subsection{Academics Begin to Advocate Climate Change Adaptation}

In the late 1990s, researchers began to promote adaptation of forestry alongside the adaptation activities at the Forestry Research Institute of Sweden. One example is "The climate change of the future," a seminar series arranged by the Royal Swedish Academy of Agriculture and Forestry (KSLA) in 1997 (see Figure 1). These seminars brought together public authorities, the private sector and scientists interested in the issue. At a seminar focusing on potential climate change risks for forestry and agricultural practices, Bert Bolin, Professor of Meteorology at Stockholm University and first Chair of the Intergovernmental Panel on Climate Change (IPCC), openly promoted adaptation: "The question is, should one take this [gradual climate change] as a warning and adjust society without too large costs in order to be prepared for what could happen? It is this strategy that I feel is justifiable in the contemporary situation instead of just waiting and not doing anything" (Bert Bolin cited in [49]).

While many participants agreed that adaptation would become necessary in the future, not everyone agreed that immediate adaptation planning and action were necessary. The written report from the meeting indicates that a majority of the participants expressed a wish for more knowledge about the vulnerability of Sweden's forestry sector to climate change [49]. 
Despite arguments in favour of further adaptation research and planning, efforts to put adaptation on the forestry policy agenda were not visible until 2002, when the KSLA set up another seminar and a "Climate and Forest Committee" [50] (interviews; see also Figure 1). The committee included five researchers from SLU, two from the Forestry Research Institute of Sweden, one from the Swedish Meteorological and Hydrological Institute (SMHI), and one from the Swedish Forest Agency. Its three aims were first, to review the literature on expected climate-related change in the Nordic countries and the potential risks to the forestry sector; and second, to stimulate the formation of an interdisciplinary programme that could increase knowledge of the biotic effects of climate change; and third, to "discuss the possible need to change the policy direction and planning in forestry with actors in the forestry sector" [51].

This last point in particular indicates an ambition to evaluate the need for an adaptation policy in the forestry sector. The committee's four years of work resulted in a comprehensive literature review and a research agenda for a future interdisciplinary research programme. The literature review concluded that there were gaps in knowledge about the potential effects of climate change on forest ecosystems, but that the most likely effects could be predicted: increased opportunities for production and increased risk of severe weather events [50,51]. These gaps prompted a two-day workshop at KSLA in 2004, where 30 scientists from a range of disciplines discussed the design of the forest-oriented interdisciplinary research programme. The workshop's goal was to “develop support tools to help decision-makers in forestry to adapt forest management practices to meet challenges posed by anticipated, but uncertain, climatic change" [51]. In 2009, these plans became reality as the Future Forests programme, with a somewhat wider objective of studying adaptation to change affecting the forestry sector in general [52].

However, the KSLA committee was not alone at this time in promoting increased support for climate change vulnerability and adaptation research. Several others e.g., [53-57] expressed the need for more knowledge on climate change, its effects on the boreal forest zone, and the need for adaptation. Interviewees indicated that this issue became established in the scientific community at the turn of the century, and a common discourse on adaptation for the Swedish, or boreal, forestry sector began to emerge. In addition, organised efforts to inform policy, such as the KLSA Climate and Forest Committee, indicate the gradual formation of an advocacy coalition for adaptation.

\subsection{Storms Trigger Policy Action}

During one night in January 2005, the storm Gudrun felled 75 million $\mathrm{m}^{3}$ of forest in the south of Sweden, a volume close to what is normally logged in the whole country over a full year. The forest damage was the worst in history from a single event [58]. A variety of climate adaptation-related policy activities were initiated the years after the storm (see Figure 1). A number of our interviewees suggested that the storm was the direct trigger for these activities, though other natural disasters and political events may have contributed (see Section 3.5 below).

Soon after storm Gudrun, the government assigned the Swedish Forest Agency to evaluate the storm's consequences. The Agency concluded that there was no reason for a complete change in forestry policy, but that improvements could be made to increase the level of preparedness for future storms. The effects of climate change were to be included in future planning tools "if possible" [58]. This vague consideration of climate change can be explained partly by the level of perceived scientific uncertainty. 
The Agency recognised that climate scenarios showed an increased likelihood of strong winds in the south of Sweden, and that the expected warmer and wetter climate increased the risk of wind-felling. However, uncertainty about how, when and where these phenomena would affect forests and interact with different ecosystems, combined with changing forestry methods and changing markets for forest products, was seen as too great a barrier to extrapolating clear policy advice (ibid.).

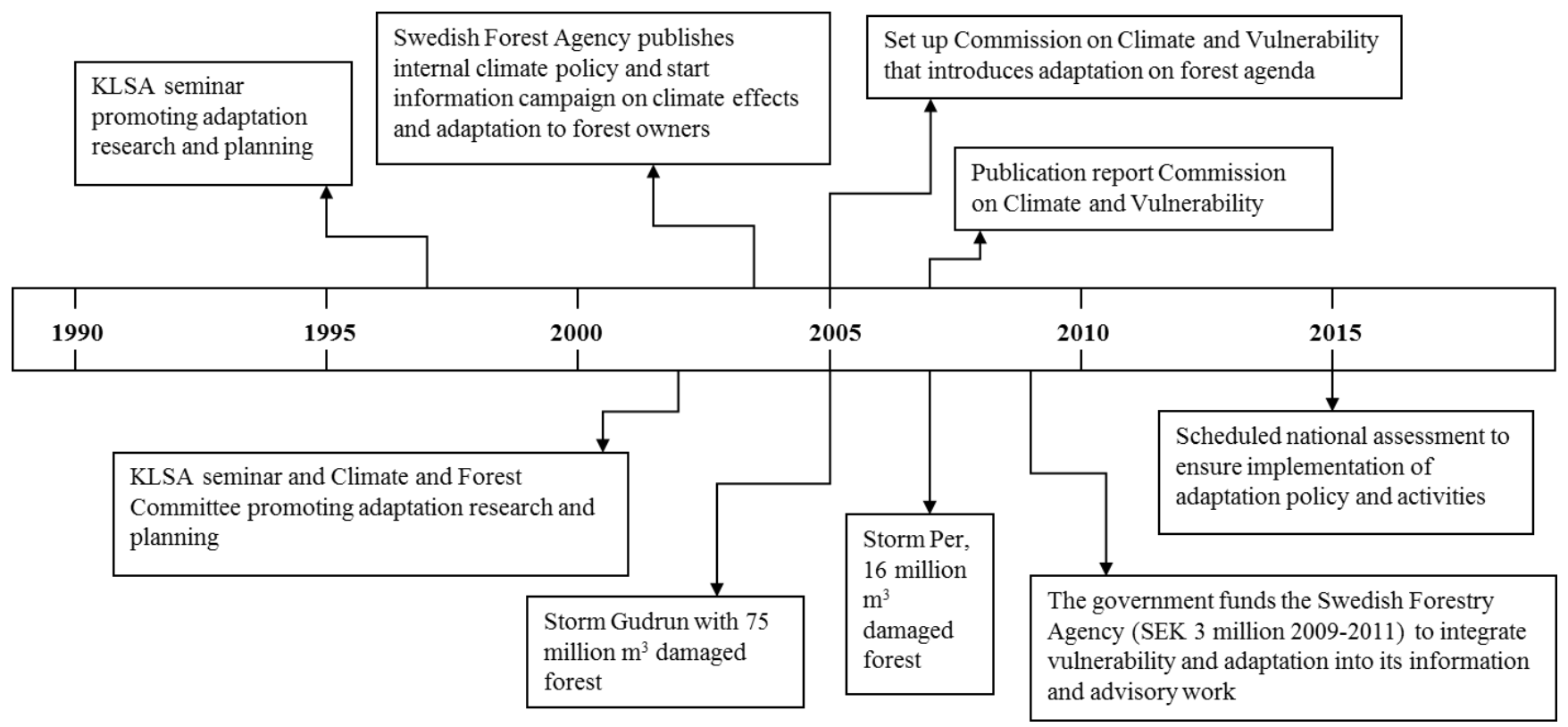

Figure 1. Timeline of the main activities and events on adaptation and forestry, 1990-2012.

Scientific uncertainty also was evident in the information campaign about climate effects and adaptation launched by the Swedish Forest Agency after the storm. A pamphlet for forest owners [54] based on an internal climate policy drawn up by the Agency in 2003 [59] (see Figure 1) was key to this campaign. However, both the internal climate policy and the pamphlet lacked straightforward recommendations on how forest owners should deal with climate change. The only clear guidance given was that there was no need to change the type of species planted before climate change was observable. The argument presented was that it is primarily young seedlings that are vulnerable to major changes in the climate while grown forests can withstand them relatively well. New recommendations on which species to plant would be forthcoming when climate impacts would begin to appear. There were also some relatively vague references to spreading risk, with an understanding that it was the forest owners' own choice whether to adapt or not $[59,60]$. While primarily motivated by the uncertainty involved, this approach also reflects the increased freedom of forest owners given in the 1993 Forestry Act.

The majority of policy responses to the storm Gudrun were taken immediately. Because only $40 \%$ of the forest owners in the storm-hit area were insured, many took a big financial hit from the damage $[61,62]$. To prevent further damage from insect infestations, the government provided three billion SEK to help forest owners speed up the clearance of felled timber [62]. Of the various measures supported, one example linked to adaptation was the support provided for planting of different tree species, aiming to increase forest diversity. Many scientists and the environmental non-governmental organisation the Swedish Society for Nature Conservation saw increasingly mixed forests as more 
resilient to weather events [63]. Consequently, 250 million SEK was dedicated to coniferous forests and 200 million SEK to mixed forests dominated by deciduous trees $[63,64]$.

Planting deciduous forests was more expensive because the saplings needed to be protected from grazing moose and roe deer. Thus, the planting resulted in at most $10 \%$ mixed forests (ibid.). The government policy reflected the strong landowner interest in planting spruce, a high-yield coniferous species. Interviewees cite Södra, a major forest owners' organisation with more than 51,000 members, as one of the few actors to openly promote spruce planting: a controversial move, as spruce was known to be especially sensitive to wind-felling and dominated the trees felled by Gudrun $[58,61,65]$. An interviewee from Södra said that the group's message was based on scientific risk calculations and was more nuanced than was generally argued: “... to get some kind of counterweight in this [replanting] debate that came and hit very hard, we said that the spruce still had its place. Actually we gave a very open message [...] but since someone dared (to say) that one should replant with spruce, the media coverage became very slanted towards the message that Södra wanted spruce."

Early in the subsidy process, the landowners' strong preference for planting coniferous trees forced the government to use part of the subsidy originally intended for mixed forests to other measures. The majority of these measures prevented the increase of harmful insects that thrived among storm-felled trees [64].

Although much weaker than Gudrun, the 2007 storm Per also contributed to the adaptation debate (see Figure 1). While stakeholders were better prepared to deal with the storm's effects, the close succession of the two storms led to much storm-felled timber, and warm, dry summers after 2007 brought increases in insect populations. Bark beetles were particularly damaging to wind-felled and standing forests, causing the death of approximately 2-3 million $\mathrm{m}^{3}$ of standing forest in 2006-2008. Since 2006, various methods have been used to curtail bark beetle numbers, including the removal of storm-felled timber and a variety of extermination methods [66]. A subsequent adaptation-related policy action was the government assignment to the Swedish Forest Agency to monitor, analyse and inform forest owners about the development and potential effects of insect populations, with scientific back-up from the Swedish University of Agricultural Sciences [67,68].

Viewed in a wider context, the debate on adaptation seems rather limited. Both the Swedish Forest Agency's storm review [58] and the policy actions post Gudrun (see also [69]) indicate a focus mainly on optimizing short-term productivity, while long-term efforts to tackle climate vulnerability and adaptation, such as government subsidies for mixed forests, were only peripheral. The disregard for long-term adaptation measures in forestry is also indicated by a recent decline in preparedness for storms among forest owners, as noted by an interviewee from Södra: "I can partly see that the knowledge is beginning to deteriorate - especially in the areas unaffected by Gudrun and Per, where the forest owners are equally unaware as they were here [in the storm-ridden areas] before the storms."

Despite the lack of long-term adaptation measures among the policy measures connected to the storms, it is clear that awareness of climate change and of adaptation needs did increase within the forestry sector during this period. 


\subsection{The Debate Takes off}

While storm Gudrun may have triggered a debate on adaptation issues in forestry, other events outside the forestry domain also contributed to Sweden's policy debate.

On an international policy level, adaptation concerns emerged in the 1980s. However, vulnerability to climate change was not fully recognised, and adaptation generally was used to argue against mitigation because nature and society would simply "adapt" to climate change [47,70]. The IPCC Third Assessment Report [1] presented adaptation and vulnerability as core issues and introduced new issues, such as the technical aspects and socio-economic impacts of climate change, which helped to introduce adaptation more broadly into the policy arena. According to Pielke et al. [70], it was through the publication of the Stern Review [71], calculating the economic costs of climate change, and of the Fourth Assessment Report [72] that the need for adaptation alongside mitigation was acknowledged by a wider policy audience.

In Sweden, vulnerability and climate change became part of a wider national discussion on crisis management through the formation of the Swedish Commission on Vulnerability and Security [73]. Nevertheless, the resulting national policy focus remained on disaster management alone [74-76]. Disastrous floods and landslides in 2001, 2002 and 2004 increased awareness of natural disasters [77]. The floods and associated regional political pressures led the government to set up a national Commission on Climate and Vulnerability [12](see Figure 1). According to interviewees at the Ministry of Environment, the storm Gudrun added a sense of urgency to the commission's work. It engaged some 150 experts to assess vulnerabilities and adaptation needs [78]. The main conclusion of the commission's 2007 report was that Sweden should start adapting to climate change and that "the main features in the climate scenarios, despite uncertainties, are sufficiently robust to be used as a foundation" for action [14].

According to a former employee at the Ministry of the Environment, the delay in addressing adaptation was a "question of political strategy" in order to maintain legitimacy for climate change mitigation efforts: "[Consecutive Swedish] environmental ministers wanted to keep the focus on an active policy to reduce emissions, not a policy for adaptation. Eventually, we came to reconsider this strategy for two reasons. First, it became ever more apparent that a policy for reducing emissions would not be sufficient. The ratification of the Kyoto Protocol was delayed, the U.S. dropped out, and researchers started to report that climate change was no longer in the future, it could already be observed. [...] Second, little by little it became ever more apparent to us that a policy for climate change adaptation did not need to imply reduced interest in a strong emissions reduction policy." (interviews)

Storbjörk [79] argues that the lack of attention for adaptation on a national policy level caused uncertainties over the division of responsibilities and hampered initiatives. In general, agencies with responsibility for providing knowledge, such as the SEPA, the SMHI, and the Swedish Geotechnical Institute, paid more attention to adaptation issues than agencies responsible for decision-making, planning and implementation of risk reduction measures.

The Commission on Climate and Vulnerability marked a shift in both national debate and policy. Reducing emissions and adapting to climate change were no longer seen as conflicting approaches but rather as complementary and equally important climate policy measures [12]. 
This commission produced the most elaborate analysis so far of the impacts of climate change on the forestry sector [14]. Its findings were similar to those of the KSLA committee: it concluded that the expected rise in temperature would contribute to increased growth and, thus, increased profits for the sector, while the damage from insects, fungi, and potential storms and forest fires would increase costs. The commission identified several adaptation policy measures, as well as areas requiring further research and knowledge dissemination.

The public consultation that followed the report revealed conflicting views on adaptation in the forestry sector. For example, SEPA [80] strongly endorsed the commission's recommendation that adaptation efforts begin immediately, but the Swedish Forest Industries Federation took a "wait and see" position, arguing that adaptation was an important issue but that "one has to be conscious of the time horizon and the risk of making rash decisions that precede research, experience and efficient use of resources" [81]. The latter position reflects the traditional approach to forest management, managing uncertainty by relying on experience [82], while scientific arguments for adaptation tend to rely on projections of deviations from historical patterns. This is likely to have contributed to the hesitance towards adaptation within the forest industry.

The most divisive aspect of the debate was the conflict between productivity and biodiversity. Both SEPA and the Swedish Biodiversity Centre (CBM) argued that the report's discussion of biodiversity was flawed and incomplete [80,83]. The CBM found that the commission's final report focused too much on the issue of increased productivity and far too little on the effects of land and resource use on biodiversity, and how these effects would interact with climate change [83]. The CBM also criticized the resulting policy recommendations for the Forestry Agency, which it deemed unacceptable at a time of growing interest in securing ecosystem services.

The CBM also warned that forest management practices were having a growing impact on forest ecosystems: "This is the way it has been up to now and this is the way it will be to an even greater extent in the future when the forestry sector is adapting to climate change" [83], p. 3. A similar line of reasoning was put forward by environmental organisations such as the Swedish Society for Nature Conservation [84] and WWF Sweden $[85,86]$. Both expressed concern about the future management of biodiversity as well as other natural and social benefits from forests if the intensification of forestry continued. Both mentioned climate change as an additional pressure on forests but, like the CBM, saw it as having less of an impact than forest management practices.

The main advocates for maintaining high levels of forest productivity were the publicly held forest company Sveaskog (the country's largest individual landowner) and the Swedish Forest Industries Federation. Both recognized that adaptation was important in order to avoid risks and secure gains for forestry, but argued that the report did not sufficiently cover the potential benefits of increased forest production, such as climate change mitigation. Their reasons for this were that: (a) forests would grow more actively and so take more carbon dioxide $\left(\mathrm{CO}_{2}\right)$ from the atmosphere; and (b) recyclable forest products could replace other non-recyclable and more carbon-intensive products. Both organisations claimed that the report did not weigh the costs and benefits of adaptation versus mitigation activities in the forestry sector $[81,87]$.

Taken together, the claims of the debate indicate a central conflict between adaptation and mitigation activities that, unlike the general climate change debate, was embedded in an old debate within the forestry sector: production versus biodiversity preservation. In this way production became strongly 
linked to mitigation, in conflict with adaptation, which was linked to biodiversity preservation. This conflict and the dominant position of production in the forestry sector, as indicated in Section 3.1, are likely to have set limits for the debate on adaptation issues in forestry.

In the public consultation following the commission's report, the strong production interests also conflicted with other policy proposals by the commission, such as one on reindeer husbandry in forests. The report found reindeer husbandry would be particularly vulnerable to climate change. To compensate for this, it suggested that the Sami, an indigenous population engaged in reindeer husbandry in northern Sweden, should have more influence over forestry in reindeer herding areas. Sveaskog [87] and the Swedish Forest Industries Federation [81] argued strongly against this recommendation, and Sveaskog [87] questioned whether the reindeer industry was as vulnerable as the commission claimed. Underlying these objections was an existing conflict in the region between forest owners and the Sami. While the Sami need access to forest owners' land so the reindeer can reach their grazing areas, the forest owners claim that the reindeer cause damage to the forests and a consequent loss of revenue.

Another conflict with the production interests was the Commission's key proposal on how to finance adaptation: (a) by the actors causing climate change; (b) by those who stand to profit from climate change; (c) through a tax to discourage undesirable adaptation measures that could, for example, have negative environmental effects; and (d) through public-private partnerships [14]. The second option was strongly opposed by both Sveaskog and the Swedish Forest Industries Federation. Sveaskog [87] highlighted the greater risks associated with climate change, and the radical and unexpected ways in which it might devastate the sector, making it "illogical" for the forestry sector to finance adaptation. The Forest Industries Federation [81] agreed, arguing that the suggestion was counterproductive and contradicted the idea that actors causing climate change should cover the costs for adaptation.

Later that year, the Parliament passed a new forestry bill - a turning point in Swedish policy [88]. The bill reasserted the view that productivity and environmental goals in forestry should carry equal weight, while at the same time prioritizing the production goal and promoting further intensification. Among the measures suggested were increased planting of foreign and fast-growing species; increased forest fertilisation, and the harvesting of tree stumps for use in the production of bioenergy (ibid.). Advocates of biodiversity protection, including environmental organisations [86,89] and some Swedish scientists, e.g., [90], strongly objected. Eklöf and Rudberg [84] note that the Swedish Forest Industries Federation launched a large-scale environmental campaign of its own, using the slogan "forestry is good for the climate", around the time that the forestry bill was introduced. The forest owners' association Södra asserted that the climate change issue would be solved if half the forests in the world were managed as they were in Sweden - a statement heavily criticised by environmental organisations (ibid.).

The debates summarised above reveal divergent opinions as well as uncertainty about how best to manage forests in the face of climate change, and whether the purpose should be to support industry and the Swedish economy, mitigate climate change, preserve biodiversity, or pursue other social aims. Adaptation was given a different meaning depending on the desired goal: whether to maximise productivity or preserve biodiversity. Thus, the debate on adaptation in forestry has both competed with and been influenced by other ongoing debates. 


\subsection{Policy Measures on the Way?}

The Commission on Climate and Vulnerability [14] recommended a number of policy measures directly relevant to forestry and adaptation, such as to gather and consolidate knowledge on ways to protect biodiversity in a changing climate. The criticism (e.g., by the CBM) against the report for neglecting the issue of land and resource use in the future protection of biodiversity was partly addressed by the commission when it recommended that the SEPA and SLU should "investigate the issue further". Moreover, the commission addressed the conflict between preserving forest biodiversity and maintaining forest productivity with its recommendation that the Forest Agency develop management advice and support for combined action on bioenergy and nature conservation.

The government followed up on the commission's recommendations in the 2008 Climate and Energy Bill. A grant of 4 million SEK was assigned to the Swedish Forest Agency for the period 2009-2011 - less than half the amount the commission had recommended - to set up a system to inform forest owners and others active in the sector about climate change and potential adaptation actions (see Figure 1). CBM had suggested that knowledge on forest management in relation to biodiversity should be increased before the information system was set up by the Forest Agency. The government agreed that knowledge was limited, but argued that it was sufficient to meet the need and for the planning purposes of landowners [83,91].

Already in 2005, the Forest Agency had disseminated information to forest owners about climate change effects and adaptation. The Rural Development Programme, set up in 2007 and co-financed by the government and the EU, provided further support for the dissemination of information [46]. However, according to an interviewee at the Forestry Agency, officials quickly realised they needed to reorganise to meet the increasing demand for action on climate change. That demand was partly due to pressure from the Ministry of Agriculture to prioritise climate issues, as well as to an increase in questions from forest owners.

Consequently, an internal group was set up within the Forestry Agency in 2007 to develop a climate strategy and revise the agency's internal 2003 climate change policy. The publication of a revised climate policy [92] coincided with the Agency being asked by the government to set up a climate information system for forest owners. The revised policy gave greater prominence to climate change and adaptation but did not differ significantly from the previous version. The agency still advised forest owners to think about the potential risks of climate change and not "put all their eggs in one basket", while giving them the freedom to make their own decisions in response to climate change.

Following the establishment of the internal climate group, the Forest Agency also held several workshops on climate change and adaptation. The agency had developed a curriculum for district employees and informational materials for forest owners even before it was mandated to do so [93]. Thus, accounts from within the Forest Agency suggest that climate and adaptation issues were already being integrated into the agency's overall practices.

In line with the commission's proposals, a new climate and energy bill [94] presented a national adaptation policy to be coordinated by county administrative boards and some sectoral authorities. A national assessment is scheduled for 2015 to ensure implementation as planned (see Figure 1). The bill laid out several measures for researching and monitoring the effects of climate change. According to Rydell et al. [91], many of these activities had already begun, such as the revision of the forest 
regeneration law and activities to support reindeer husbandry. Some initiatives had already been completed before the introduction of the 2009 bill, such as an evaluation of how to reach the "sustainable forests" objective in the context of climate change (ibid). Other activities had been initiated, such as the expansion and improved public access to early-warning systems on extreme weather [95]. Several more have started only recently, such as a SEPA-led evaluation of the potential for improving current systems to enable the migration of species [96], and the SLU and Forest Agency's development of support on how to combine bioenergy and nature conservation [83]. The Rural Development Programme shares a similar ambition by providing financial support to forest owners to secure biodiversity and sustainable forestry. In an effort to promote adaptive forest management in the face of climate change, the Rural Development Programme has over the past years implemented two projects that offer advice and training to forest owners, "Forestry in a Changing Climate" and "The Forest Owner and the Climate". In addition, a series of seminars and meetings has been arranged across Sweden [97,98].

\section{Discussion}

The previous section summarised the gradual integration of climate and adaptation concerns within Swedish forestry during the years 1990-2012. As is obvious from our analysis, plausible causal relationships cannot link outcomes over these years to particular events or changes in policy and legislation. Nevertheless, using the analytical perspective offered by the advocacy coalition framework (ACF) - notably its key concepts of advocacy coalitions, combined with an application of the four hypotheses we listed above, we can pinpoint different aspects of the nature of the change that has been observed, as well as the barriers and opportunities that shaped this integration path. We elaborate on each hypothesis and related observations below.

First, in line with Hypothesis 1, conventional ways of thinking within the forestry sector-reflected in policy core beliefs about forestry productivity and the key role of forests in climate change mitigation-have blocked adaptation concerns.

As climate change first became a significant environmental problem, many dominant actors, in Sweden as well as internationally, perceived adaptation as incompatible with mitigation. Arguments in support of adaptation even were perceived as a denial of the need for emission reductions. In Sweden, adaptation was not addressed properly at the national level until the establishment of the Climate and Vulnerability Commission in 2006.

This conflict extended into the forestry sector and policy environment. The two key advocacy coalitions in the forestry sector, the forest production and environmental conservation coalitions (see Table 1), primarily were concerned with the mitigation aspect of the climate problem and resisted the introduction of adaptation issues within forestry, for fear that it would detract from their key concerns. With the public consultation of the Climate and Vulnerability Commission in 2007, these actors were persuaded to join the adaptation discussion. However, the adaptation versus mitigation debate found new life within an old conflict between the key coalitions in the forestry sector. The forest industries representing the production coalition argued that sustained and even increased forest production was needed to combat climate change, and presented adaptation to preserve biodiversity as a potential threat to the emission reduction ambitions. On the other side, some environmental 
organisations and researchers argued that prioritizing production harmed biodiversity and argued for adaptation measures as means to safeguard and increase biodiversity.

Second, regarding Hypothesis 2, the nature of the advocacy coalition on climate change adaptation did determine the extent to which the debate was influenced. We found that the lack of a coordinated and strategically resourceful advocacy coalition for adaptation, particularly at an early stage, also served as a barrier to the integration of adaptation into forest policy. Even now, adaptation is only one of many concerns for the dominant forest actors, and there are no politically influential actors within the Swedish forestry sector that push adaptation as a key priority. A lack of clear leadership on adaptation has resulted in weak organisation and disjointed promotion of the issue in the sector.

Scientists have encouraged research on climate change and increased preparedness since the early 1990s, and in the late 1990s and early 2000s the KSLA served as an arena for building an academic advocacy coalition for adaptation. However, the scientists' concerns were not shared by the forestry industry or government agencies at the national and local levels. A broader advocacy coalition only emerged after the storm Gudrun and the establishment of the Commission on Climate and Vulnerability (See Table 1).

Third, according to Hypothesis 3, events influenced the integration of adaptation issues. External events have raised the profile of adaptation in the forestry sector. The storm Gudrun in particular, with its extensive damage to forests, significantly increased awareness of climate change impacts and adaptation needs within the forestry sector, and it added legitimacy to the efforts of advocacy coalitions to put adaptation on the forest policy agenda. Local and international developments, such as reoccurring floods in Sweden and the increased adaptation focus of the IPCC, stimulated the Commission on Climate and Vulnerability as well (The influence of the IPCC has parallels with epistemic communities as described by Haas [99]). Although these external events triggered learning and policy change, they did not affect policy core beliefs enough to fully integrate adaptation concerns into forestry policy. In addition, the slow progress that has occurred needs to be understood in the broader context that we discuss below.

Fourth, in agreement with Hypothesis 4, different types of learning processes have been influencing the adaptation integration processes in different ways. We give examples of two types, double loop and single loop learning. First, a key step in the adaptation learning process which played out on the national level and later spread into the forest sector was the recognition that mitigation and adaptation are not necessarily conflicting issues. While academics realised this much earlier, it was not until 2007 that this idea began to take hold within the Swedish forestry community. This opened the door for a more diverse debate on how far Swedish forestry practices should change to capitalise on opportunities and to reduce the risks associated with climate change. The acceptance of adaptation as possible and legitimate alongside mitigation indicates that the old national-level policy core beliefs had given way for new ones related to adaptation. This is an early sign of double-loop learning, or learning across rival advocacy coalitions. This emerging learning process has, according to our analysis, been facilitated by the public debate initiated by the national Commission on Climate and Vulnerability. On a forestry subsystem level this learning process also resulted in agenda setting favouring adaptation. While it did not change the core beliefs of key advocacy coalitions, it nevertheless helped a continuous dialogue emerge.

While acknowledgement of adaptation needs across the forestry sector has put adaptation firmly on the policy agenda, cognitive path dependencies appear to still hinder further progress. As of 2012 there 
was still a perceived conflict between the key coalition actors: those who want to maintain high levels of production, arguing that the best response to uncertainties about future climate change is to "wait and see", and those who want to take adaptation actions that protect biodiversity only.

A second type of learning process that influenced the integration of adaptation was single-loop learning facilitated by arenas. Arenas for multi-stakeholder deliberation and learning on adaptation have been important in Swedish forestry policy responses to climate change. The KSLA and the Commission on Climate and Vulnerability played key roles in creating such arenas. The KSLA's seminars and committee created a space for scientists to meet, debate, and share and co-create knowledge. The commission had a similar function, but expanded the production of knowledge by inviting key and rival advocacy coalitions to participate in public debate.

These arenas were part of the many processes that aided the acceptance of adaptation within the forestry sector. In particular the public debate following the commission facilitated sufficient cross-coalition learning for a wider acceptance of adaptation next to mitigation. It also indicated some of the conditions for successful cross-coalition learning outlined by ACF, i.e., the involvement of all relevant stakeholders facilitated by a neutral policy broker [28,32]. Nevertheless, the exploration of adaptation concerns has been hindered by the dominance of the belief that high forest yields should be the priority, and by the conflict with advocates for biodiversity protection. Only minor advances in the policy process at the subsystem of forestry policy seem to have occurred, resting solely on what Argyris and Schön calls single-loop lessons.

Table 1 shows how our key observations fit within the key ACF concepts analysed in a twofold manner. First, it shows how the key coalition actors in the forestry subsystem have reacted to the growing adaptation debate and how their response has created barriers to and opportunities for adaptation. Second, it shows how the adaptation coalition has emerged and gained increased public recognition in reaction to learning activities and events. Our findings indicate that the core value in the adaptation coalition remains stable over time.

When relating our findings to previous ACF-literature on forestry, our findings indicate no notable conflict with the definition of the production coalition and the environmental conservation coalition made by more thorough ACF studies $[25,26]$ summarised in Section 3.1. Table 1 indicates that the key coalition actors visible in our analysis were fewer, but still part of the key coalition actors identified by Hysing and Olsson [26]. Similar to the findings by Winkel et al. [27] in his case study on the German forest sector and in other cases to which he refers (see p. 383), we find that the core value of key coalitions remains stable over time. In addition we share the finding of incremental learning and strategic adjustments in framing related to the new issue at hand. In our case, such learning and reframing activities were triggered by the storms and the Commission on Climate and Vulnerability (see Table 1). The stability in key values implies that the critique of ACF - that it is too rigid for analyzing policy processes - does not hold in these particular forestry cases. 
Table 1. Summary of barriers to and opportunities for integrating adaptation in the Swedish forestry sector according to key ACF concepts.

\begin{tabular}{|c|c|c|c|c|c|}
\hline $\begin{array}{c}\text { Key Advocacy } \\
\text { Coalitions }\end{array}$ & Key Coalition Actors & Key Value Priority & $\begin{array}{c}\text { Key Learning } \\
\text { Processes/Events }\end{array}$ & General Perspective on Adaptation & $\begin{array}{c}\text { Effect for } \\
\text { Adaptation }\end{array}$ \\
\hline Production & $\begin{array}{l}\cdot \text { Swedish Forest Industries } \\
\text { Federation } \\
\cdot \text { Forest company Sveaskog }\end{array}$ & $\begin{array}{l}\text { Economic importance of } \\
\text { forestry and forest } \\
\text { industry }\end{array}$ & $\begin{array}{l}\text { Early climate change } \\
\text { beliefs } \\
\text { Commission on climate } \\
\text { and vulnerability }\end{array}$ & $\begin{array}{l}\text { Forests play a key role for mitigation. Adaptation ignored, due to } \\
\text { conflict with mitigation } \\
\text { Adaptation recognized, but should wait until greater ability to define } \\
\text { climate impacts. Continued focus on production for mitigation. }\end{array}$ & $\begin{array}{l}\text { Barrier } \\
\text { Opportunity/ } \\
\text { Barrier }\end{array}$ \\
\hline \multirow{2}{*}{$\begin{array}{l}\text { Environment } \\
\text { conservation }\end{array}$} & \multirow[t]{2}{*}{$\begin{array}{l}\cdot \text { Selected environmental } \\
\text { organizations }\end{array}$} & \multirow{2}{*}{$\begin{array}{l}\text { Protection of the } \\
\text { ecological integrity of } \\
\text { forests (biodiversity } \\
\text { preservation) }\end{array}$} & $\begin{array}{l}\text { Early climate change } \\
\text { beliefs }\end{array}$ & Forests play a key role for mitigation & Barrier \\
\hline & & & $\begin{array}{l}\text { Storms and Commission } \\
\text { on climate and } \\
\text { vulnerability }\end{array}$ & $\begin{array}{l}\text { Adaptation and mitigation measures can co-exist. Mixed forests } \\
\text { (increased biodiversity) are more resilient. Prevents wind felling and } \\
\text { related negative effects such as outbreaks of pests and bugs }\end{array}$ & Opportunity \\
\hline $\begin{array}{c}\text { Emerging Advocacy } \\
\text { Coalition }\end{array}$ & Key Coalition actors & Key Value Priority & $\begin{array}{c}\text { Key Learning } \\
\text { Activities/External } \\
\text { Events }\end{array}$ & Effect on Adaptation Coalition and Measures & \\
\hline Adaptation & $\cdot$ Scientists & $\begin{array}{l}\text { Adaptation required to } \\
\text { prevent risks of climate } \\
\text { change, despite } \\
\text { uncertainty about } \\
\text { impacts }\end{array}$ & $\begin{array}{l}\text { KSLA seminar } \\
\text { KSLA Climate and Forest } \\
\text { Committee } \\
\text { Internal climate policy by } \\
\text { Swedish Forest Agency } \\
\text { Storms and Commission } \\
\text { on climate and } \\
\text { vulnerability }\end{array}$ & $\begin{array}{l}\text { Recognition of adaptation by the Swedish Forest agency, but no real } \\
\text { Increases public urgency for adaptation and results adaptation related } \\
\text { and initial policy measures executed by the Swedish Forest Agency a }\end{array}$ & $\begin{array}{l}\text { measures. } \\
\text { d activities } \\
\text { and others. }\end{array}$ \\
\hline
\end{tabular}


Winkel et al.'s [27] study on the introduction of sustainability issues in German forestry showed that such incremental learning led to the development of new policies and guidelines that combined polarized values. A comparable policy development pattern is visible in the Swedish case (see Section 3.1). As a result Winkel reports that the policies and guidelines were sometimes unclear or contradictory, leading to legal debates. Nevertheless, they led to increased integration of sustainability issues in the forestry sector, although in different ways by different actors. Similar findings are found in De Koning et al.,'s [100] study on the effects of the climate adaptation debate on the EU Natura 2000. They stress that actors with polarized perspectives may by means of shared strategies, or storylines about problems and solutions, realize policy change without fully agreeing or understanding each other. Offermans and Cörvers [101] even argue that such shared strategies can lead to socially robust action, e.g., policy plans or strategies, which is able to preserve support despite changing views and circumstances.

Our analysis shows that the Swedish environmental conservation coalition has applied such framing strategies on adaptation to a larger extent than did the production coalition (see Table 1). While international cases [102] show that the forest industry could use climate adaptation to argue for increased production, key actors in the Swedish production coalition so far show limited interest in and initiative for such strategic adaptation framing.

These findings lead us to conclude that alternative understandings of adaptation may co-exist and evolve into policies and practice in parallel through incremental learning. However, from a policy perspective we still believe in the promotion of learning processes across coalitions. Adaptation policies with wide support of key advocacy coalitions are likely to become more consistent, have greater effect, and be more sustainable. After all there is more evidence for sustainable effects of such learning in the ACF and learning literature e.g., [34,35,103-105] compared to the incremental learning strategies presented above.

To sum up, our findings are very much in line with the main ACF assumptions part of our hypotheses, e.g., that there is the need for: (i) apt advocacy coalitions that have the appropriate resources to influence policy; (ii) events creating opportunities for such influence; and (iii) suitable learning processes for change in policy core beliefs to come about. However, policy core beliefs were not only barriers to policy change as a result of ignoring or resisting the influence of new beliefs. The nature of the policy debate between the key coalitions and related policy core beliefs, e.g., the conflict between production versus environmental conservation beliefs, implied that the influence of the new beliefs on policy remained limited. Hence, with this work we propose a new hypothesis to be explored more thoroughly in future ACF analyses: The nature of the policy debate can provide barriers for policy change.

\section{Conclusions}

Our analysis of the evolution of climate change adaptation concerns in the Swedish forestry debate and policy from 1990 to 2012 indicates that integration of adaptation concerns has been slow and limited in its scope.

The message from the ACF literature is that incremental learning within coalitions, so-called single loop learning, (i.e., correcting errors from routines) is not sufficient to bring about long-term change in policy framing and policy directions. Earlier work testifies to the importance of cross-coalition, double-loop learning (i.e., examining and questioning existing values and policies), to bring new, often 
competing issues and priorities into the Swedish forestry discourse and policy agenda. Stimulating the latter is crucial to promote a more fundamental shift in the governance structures that appear ideal for recognizing adaptation needs and for building adaptive capacity to climate change within the sector. For this reason, based on our study we do not consider the learning pattern to date within Swedish forestry, dominated by incremental single-loop learning, to be sufficient to change the current policy direction.

Despite this, our results indicate that there has been an increasing recognition in recent years of the value of adapting to climate change, alongside other forestry objectives, within the Swedish forestry sector. For instance, adaptation has become an integral part of the advisory and information activities of the Swedish Forest Agency, and these activities have gained further momentum as a result of the Rural Development Programme. Climate change now also features more prominently in the advice on planting and forest management given by the Forestry Research Institute of Sweden and forest owner associations. Additional policy advances have been made as a result of the government assignments following the recommendations of the Commission on Climate and Vulnerability, such as the various measures for researching and monitoring the effects of climate change, and an early warning system for severe weather events see $[91,95]$. An activity of particular interest is the ongoing work by the SLU and the Swedish Forest Agency to bridge bioenergy and natural conservation interests into one advisory and support system see [83] considering that these conflicting interests previously have hampered the integration of adaptation issues in the forestry debate and policy.

Still, whether the extent to which adaptation concerns have been translated into policy is sufficient is open to debate. Policymakers need to continue to learn from one another and to create opportunities for different perspectives to be heard. This lends support to other studies which point at the limited number of private forest owners who acknowledge climate change as a serious risk [18], and their inadequate capacity to adapt to climate change due to other increasingly pressing socio-economic challenges [19]. Policymakers need to consider an approach to protecting the future that integrates a range of economic, social, cultural and environmental interests tied to forests, not only dominant interests such as forest yields and biodiversity. In this way, new sustainable policy pathways can be developed.

Some may argue that resistance to adaptation within the Swedish forestry sector is justifiable because the sector has bigger challenges on which to focus or simply because there are alternative views on climate vulnerability. After all, the Commission on Climate and Vulnerability [14] concluded that the sector will be one of the least harmed by climate change in Sweden, and may even benefit due to the expectation of increased forest growth. However, even harnessing benefits from climate change will require adaptation, especially since these opportunities will inevitably be accompanied by increased risks to the economy of the sector. Example of risks that the Swedish Forest Agency [67] see necessary to adapt to are increased pests, pathogens and heavy shifts in temperature causing forest damage. Other risks are increased wind fellings and increased difficulties in logging and transportation due to reduced ground frost. Hence, a continued focus on the development of adaptation measures for forestry policy and practice will be essential.

It is reasonable to believe that responding to climate change will continue to be an important issue for forestry for decades to come, in Sweden as well as internationally. The future will reveal how climate change is taken into consideration in the forthcoming National Forest Programme that may be launched as early as 2016 [106]. A key lesson from our study is that barriers can be overcome, as proven by the growing recognition of climate change mitigation and adaptation as complementary not conflicting. 
Another lesson is the importance of a strong advocacy coalition with influential actors and strong leaders to further policy integration. Policymakers and authorities worldwide can stimulate the formation of such coalitions by taking a clearer position and promoting strategic action on adaptation through investment, regulation and provision of advice.

At this stage of integrating adaptation in the Swedish forestry sector, continued cross-coalition or double-loop learning in multiple stakeholder arenas seems to be a promising strategy in the new era after the Commission on Climate and Vulnerability process. As the need for adaptation develops in the coming years, organizations and policy-makers will continue to play an important role in setting up and nurturing such spaces for deliberation and learning.

\section{Acknowledgments}

The authors acknowledge the financial support of the Swedish Foundation for Strategic Environmental Research (Mistra). The authors are grateful to all the interviewees and the participants in the stakeholder meetings for making this work possible. Our appreciation also goes to our colleague Karin André (SEI) and Louise Simonsson (Swedish Defence Research Agency, FOI) of the Mistra-SWECIA programme and Maja Dahlin for contributing to the data gathering. In addition, Annika Nilsson, Richard J.T. Klein, Marion Davis, Tom Gill, Elaine Beebe and at SEI and Katarina Eckerberg at Umeå University and anonymous reviewers provided valuable comments on earlier drafts.

\section{Authors Contributions}

Johanna Ulmanen is the lead author of this paper. She has had the key responsibility and has carried out the main bulk of work regarding the design of theoretical approach, method, data gathering and analysis. Åsa Gerger Swartling and Oskar Wallgren have set the initial design of the research project, attracted funds and contributed considerably with constructive critique and writing on several versions of the manuscript.

\section{Conflicts of Interest}

The authors declare no conflict of interest.

\section{References}

1. IPCC. Climate Change 2001: The Scientific Basis: Contribution of Working Group I to the Third Assessment Report of the Intergovernmental Panel on Climate Change; Cambridge University Press: Cambridge, UK, 2001.

2. Burton, I.; Huq, S.; Lim, B.; Pilifosova, O.; Schipper, E.L. From impacts assessment to adaptation priorities: The shaping of adaptation policy. Clim. Policy 2002, 2, 145-159.

3. Füssel, H.-M.; Klein, R.J.T. Climate Change Vulnerability Assessments: An Evolution of Conceptual Thinking. Clim. Chang. 2006, 75, 301-329.

4. Moser, S.C.; Ekstrom, J.A. A framework to diagnose barriers to climate change adaptation. Proc. Natl. Acad. Sci. USA 2010, 107, 22026-22031. 
5. Adger, W.N. Social Capital, Collective Action, and Adaptation to Climate Change. Econ. Geogr. 2003, 79, 387-404.

6. Adger, W.N.; Dessai, S.; Goulden, M.; Hulme, M.; Lorenzoni, I.; Nelson, D.R.; Naess, L.O.; Wolf, J.; Wreford, A. Are there social limits to adaptation to climate change? Clim. Chang. 2009, 93, 335-354.

7. Agrawal, A.; Kononen, M.; Perrin, N. The Role of Local Institutions in Adaptation to Climate Change. Social Development Working Papers; The World Bank: Washington, DC, USA, 2009.

8. Inderberg, T.H.; Eikeland, P.O. Limits to adaptation: Analysing institutional constraints. In Adapting to Climate Change: Thresholds, Values, Governance; Adger, W.N., Lorenzoni, I., O’Brien, K.L., Eds.; Cambridge University Press: Cambridge, UK; New York, NY, USA, 2009.

9. Rodima-Taylor, D.; Olwig, M.F.; Chhetri, N. Adaptation as innovation, innovation as adaptation: An institutional approach to climate change. Health Impacts Glob. Clim. Chang. Geogr. Perspect. 2012, 33, 107-111.

10. Eriksen, S.; Selboe, E. The social organisation of adaptation to climate variability and global change: The case of a mountain farming community in Norway. Appl. Geogr. 2012, 33, 159-167.

11. Ford, J.D., Berrang-Ford, L., Eds. Climate Change Adaptation in Developed Nations-From Theory to Practice; Springer: Dordrecht, The Netherlands, 2011.

12. Keskitalo, E.C.H. Developing Adaptation Policy and Practice in Europe: Multi-Level Governance of Climate Change; Springer: Dordrecht, The Netherlands, 2010.

13. Swedish Forest Industries Federation. Skogsindustrin-En Faktasamling. Branschstatistik 2013; Swedish Forest Industries Federation: Stockholm, Sweden, 2014.

14. Swedish Commission on Climate and Vulnerability. Sweden Facing Climate Change-Threats and Opportunities; SOU 2007:60, Fritzes: Stockholm, Sweden, 2007.

15. Lindner, M. How to adapt forest management in response to the challenges of climate change? In Climate Change and Forest Genetic Diversity: Implication for Sustainable Forest Management in Europe; Koskela, J., Buck, A., Tessier du Cros, E. Eds.; Bioversity International: Rome, Italy, 2007, pp. 31-42.

16. Seidl, R.; Lexer, M.J. Forest management under climatic and social uncertainty: Trade-offs between reducing climate change impacts and fostering adaptive capacity. J. Environ. Manag. 2013, 114, 461-469.

17. Royal Swedish Academy of Agriculture and Forestry. The Swedish Forestry Model; Royal Swedish Academy of Agriculture and Forestry: Stockholm, Sweden, 2009.

18. Blennow, K.; Persson, J. Climate change: Motivation for taking measure to adapt. Glob. Environ. Chang. 2009, 19, 100-104.

19. Keskitalo, E.C.H. Vulnerability and adaptive capacity in forestry in northern Europe: A Swedish case study. Clim. Chang. 2008, 87, 219-234.

20. Keskitalo, E.C.H. Governance in vulnerability assessment: The role of globalising decision-making networks in determining local vulnerability and adaptive capacity. Mitig. Adapt. Strateg. Glob. Chang.2009, 14, 185-201.

21. Seidl, R.; Blennow, K. Pervasive Growth Reduction in Norway Spruce Forests following Wind Disturbance. PLoS One 2012, 7, e33301. 
22. Sabatier, P.A.; Jenkins-Smith, H.C. The Advocacy Coalition Framework: An Assessment. In Theories of the Policy Process, 1st ed.; Sabatier, P.A., Ed.; Westview Press: Boulder, CO, USA, 1999; pp. 117-166.

23. Radaelli, C.M. The role of knowledge in the policy process. J. Eur. Public Policy 1995, 2, 159-183.

24. Davis, C.; Davis, S. Analyzing Change in Public Lands Policymaking: From Subsystems to Advocacy Coalitions. Policy Stud. J. 1988, 17, 3-24.

25. Elliott, C.; Schlaepfer, R. Understanding forest certification using the Advocacy Coalition Framework. For. Policy Econ. 2001, 2, 257-266.

26. Hysing, E.; Olsson, J. Contextualising the Advocacy Coalition Framework: Theorising change in Swedish forest policy. Environ. Polit. 2008, 17, 730-748.

27. Winkel, G.; Gleißner, J.; Pistorius, T.; Sotirov, M.; Storch, S. The sustainably managed forest heats up: discursive struggles over forest management and climate change in Germany. Crit. Policy Stud. 2011, 5, 361-390.

28. Weible, C.M.; Sabatier, P.A.; McQueen, K. Themes and Variations: Taking Stock of the Advocacy Coalition Framework. Policy Stud. J. 2009, 37, 121-140.

29. Sotirov, M.; Memmler, M. The Advocacy Coalition Framework in natural resource policy studies-Recent experiences and further prospects. Polit. Theory For. Policy 2012, 16, 51-64.

30. Sabatier, P.A. The need for better theories. In Theories of the Policy Process, 1st ed.; Sabatier, P.A., Ed.; Westview Press: Boulder, CO, US, 1999; pp. 3-18.

31. Zahariadis, N. Comparing three lenses of policy choice. Policy Stud. J. 1998, 26, 434-448.

32. Sabatier, P.A. An advocacy coalition framework of policy change and the role of policy-oriented learning therein. Policy Sci. 1988, 21, 129-168.

33. Scott, J.C. Seeing Like a State: How Certain Schemes to Improve the Human Condition Have Failed; Yale University Press: New Haven, CT, USA, 1998.

34. Argyris, C.; Schön, D. Organizational Learning: A Theory of Action Perspective; Addison-Wesley: Reading, MA, USA, 1978.

35. Argyris, C.; Schön, D. Organizational Learning II: Theory, Method and Practice; Addison-Wesley: Reading, MA, USA, 1996.

36. Fischer, F. Reframing Public Policy: Discursive Politics and Deliberative Practices: Discursive Politics and Deliberative Practices; Oxford University Press: Oxford, UK; New York, NY, USA, 2003.

37. Hajer, M.A. The Politics of Environmental Discourse: Ecological Modernization and the Policy Process; Clarendon Press: Oxford, UK, 1995.

38. Yin, R.K. Case Study Research: Design and Methods; SAGE: London, UK, 2009.

39. Yin, R.K. Qualitative Research from Start to Finish; Guilford Press: New York, NY, USA, 2011.

40. Törnqvist, T. Skogsrikets arvingar: En sociologisk studie av skogsägarskapet inom privat, Enskilt Skogsbruk; Sveriges Lantbruks Univ.; Inst. för Skog-Industri-Marknad Studier: Uppsala, Sweden, 1995.

41. Appelstrand, M. Miljömålet i skogsbruket—Styrning och frivillighet. Ph.D. Thesis, Lund University, Lund, Sweden, 2007. 
42. Sundström, G. Målstyrningen Drar åt Skogen: Om Government och Governance i Svensk Skogspolitik; Stockholm Centre for Organizational Research: Stockholm, Sweden, 2005.

43. Swedish Government. Svenska Miljömål. Miljöpolitik för ett Hållbart Sverige; Prop. 1997/98:145; Government offices of Sweden: Stockholm, Sweden, 1998.

44. SEPA. Sustainable Forests. Environmental Objectives; Swedish Environmental Protection Agency: Stockholm, Sweden, 2009.

45. Sollander, E.; Karlsson, S.; Eriksson, H. Skogliga Sektorsmål: Förutsättningar Och Bakgrundsmaterial; Swedish Forest Agency: Jönköping, Sweden, 2005.

46. Swedish Forest Agency. Landsbygdsprogrammet. Available online: http://www.skogsstyrelsen.se/ Myndigheten/Projekt/Landsbygdsprogrammet/ (accessed on 27 January 2013).

47. Nilsson, A.E.; Swartling, Å.G.; Eckerberg, K. Knowledge for local climate change adaptation in Sweden: Challenges of multilevel governance. Local Environ. 2012, 17, 751-767.

48. Rummukainen, M.; Rydell, B.; Persson, G.; Ressner, E. Anpassning till Klimatförändringar: Kartläggning av Arbete med Sårbarhetsanalyser, Anpassnings Behov och Anpassninsåtgärder $i$ Sverige till Framtida Klimatförändring; Swedish Meteorological and Hydrological Institute: Norrköping, Sweden, 2005.

49. Nählinder, L. Framtida Klimatförändringar: Konferenser den 15 Oktober 1997 Och den 19 November 1997; Royal Swedish Academy of Agriculture and Forestry: Stockholm, Sweden, 1998.

50. Sonesson, J. Climate Change and Forestry in Sweden-A Literature Review; Royal Swedish Academy of Agriculture and Forestry: Stockholm, Sweden, 2004.

51. Sonesson, J. Klimatet och Skogen-Underlag för Nationell Forskning: Report from the Climate and the Forest Committee; Royal Swedish Academy of Agriculture and Forestry: Stockholm, Sweden, 2006.

52. Future Forests. Arsrapport 2009; Swedish University of Agricultural Sciences: Umeå, Sweden, 2010.

53. Bergh, J.; Linder, S.; Lundmark, T.; Elfving, B. The effect of water and nutrient availability on the productivity of Norway spruce in northern and southern Sweden. For. Ecol. Manag. 1999, 119, $51-62$.

54. Blennow, K.; Sallnäs, O. Risk Perception among Non-industrial Private Forest Owners. Scand. J. For. Res. 2002, 17, 472-479.

55. Linder, M. Developing adaptive forest management strategies to cope with climate change. Tree Physiol. 2000, 20, 299-307.

56. Sonesson, J. Skogsodlingsmaterial för Framtidens Klimat; Forestry Research Institute of Sweden: Uppsala, Sweden, 2001.

57. Sykes, M.T.; Prentice, I.C. Boreal Forest Futures: Modelling the Controls on Tree Species Range Limits and Transient Responses to Climate Change. In Boreal Forests and Global Change; Apps, M.J., Price, D.T., Wisniewski, J., Eds.; Springer: Dordrecht, The Netherlands, 1995; pp. 415-428.

58. Swedish Forest Agency. Stormen 2005-En Skoglig Analys; Swedish Forest Agency: Jönköping, Sweden, 2006. 
59. Swedish Forest Agency. Klimatpolicy för Skogsvårdsorganisationen (SVO); Swedish Forest Agency: Jönköping, Sweden, 2003.

60. Fransila, J.; Malmhäll, J.; Eriksson, H. Klimatförändringar och Deras Inverkan på Skogsbruket; Swedish Forest Agency: Jönköping, Sweden, 2005.

61. Blennow, K. Risk management in Swedish forestry-Policy formation and fulfilment of goals. $J$. Risk Res. 2008, 11, 237-254.

62. Svensson, S.A.; Bohlin, F.; Bäcke, J.-O.; Hultåker, O.; Ingemarson, F.; Karlsson, S.; Malmhäll, J. Ekonomiska och Sociala Konsekvenser i Skogsbruket av Stormen Gudrun; Swedish Forest Agency: Jönköping, Sweden, 2006.

63. Hermansson Török, E. Ny Sårbar Barrskog Planteras efter Gudrun. EcoSensus, 2 February 2006, p. 1.

64. Swedish Forest Agency. Skogsstyrelsens Årsredovisning 2010; Swedish Forest Agency: Jönköping, Sweden, 2011.

65. SkogsEko. Så drabbades de olika trädslagen. Avaliable online: http://www.skogsstyrelsen.se/ Aga-och-bruka/Skogsbruk/Skogseko/Artikelregister/ (accessed on 12 March 2015).

66. Bergquist, J. Skogsproduktion i Stormområdet: Ett underlag för Skogsstyrelsens Strategi för Uthållig Skogsproduktion; Swedish Forest Agency: Jönköping, Sweden, 2009.

67. Swedish Forest Agency. Beredskap Vid Skador På Skog; Swedish Forest Agency: Jönköping, Sweden, 2012.

68. Svensson, L. Övervakning av Insektsangrepp —Slutrapport Från Skogsstyrelsens Regeringsuppdrag; Swedish Forest Agency: Jönköping, Sweden, 2007.

69. Gardiner, B.; Blennow, K.; Carnus, J.-M.; Fleischer, P.; Ingemarson, F.; Landmann, G.; Lindner, M.; Marzano, M.; Nicoll, B.C.; Orazio, J.-L.; et al. Destructive Storms in European Forests: Past and Forthcoming Impacts. Available online: http:/www.efi.int/files/attachments/efiatlantic/ 2010-storm/storms_final_report_main_text.pdf(accessed on 12 March 2015).

70. Pielke, R.; Prins, G.; Rayner, S.; Sarewitz, D. Climate change 2007: Lifting the taboo on adaptation. Nature 2007, 445, 597-598.

71. Stern, N. The Economics of Climate Change: The Stern Review; Cambridge University Press: Cambridge, UK, 2007.

72. IPCC. Climate Change 2007: Impacts, Adaptation and Vulnerability. Contribution of Working Group II to the Fourth Assessment Report of the Intergovernmental Panel on Climate Change; Cambridge University Press: Cambridge, UK, 2007.

73. Swedish Commission on Vulnerability and Security. Vulnerability and Security in a New Era: A Summary; SOU 2001:41, Fritzes: Stockholm, Sweden, 2001.

74. Ministry of Defence. Alltid redo! En ny Myndighet mot Olyckor och Kriser; SOU 2007:31, Fritzes: Stockholm, Sweden, 2007.

75. Swedish Government. Samhällets Säkerhet Och Beredskap; Prop. 2001/02:158; Government Offices of Sweden: Stockholm, Sweden, 2002.

76. Swedish Government. Samverkan vid Kris-För ett Säkrare Samhälle; Prop. 2005/06:133; Government Offices of Sweden: Stockholm, Sweden, 2006. 
77. Swedish Government. Effekterna av Klimatförändringar Och hur Samhällets Sårbarhet för Dessa kan Minskas; Kommittédirektiv 2005:80, Government Offices of Sweden: Stockholm, Sweden, 2005.

78. Swedish Government. Nationell Klimatpolitik $i$ Global Samverkan; Prop. 2005/06:172; Government Offices of Sweden: Stockholm, Sweden, 2006.

79. Storbjörk, S. Klimatanpassning i Sverige: Drivkrafter och Utmaningar för Riskhantering och Fysisk Planering; Centre for Climate Science and Policy Research, Linköping University: Linköping, Sweden, 2006.

80. SEPA. Yttrande. Slutbetänkande av Klimat-Och Sårbarhetsutredningen: Sverige Inför Klimatförändringarna: Hot Och Möjligheter (SOU 2007:60); Swedish Environmental Protection Agency: Stockholm, Sweden, 2008.

81. Swedish Forest Industries Federation. Remissyttrande. Slutbetänkande av Klimat Och Sårbarhetsutredningen. Sverige Inför Klimatförändringarna: Hot Och Möjligheter; Swedish Forest Industries Federation: Stockholm, Sweden, 2008.

82. Blennow, K.; Eriksson, H.M. Riskhantering i Skogsbruket; Swedish Forest Agency: Jönköping, Sweden, 2006.

83. CBM. Remissvar: Klimat- Och Sårbarhetsutredningens Slutbetänkande; Swedish Biodiversity Centre, Swedish University of Agricultural Sciences: Uppsala, Sweden, 2008.

84. Eklöf, G.; Rudberg, J. Världens Skogar-Mer än Bara Kolsänkor. Knäckfrågor för Klimatet; Swedish Society for Nature Conservation: Stockholm, Sweden, 2009.

85. WWF Sweden. Världsnaturfonden WWF om Svensk Skog Och Skogsbruk; WWF Sweden: Solna, Sweden, 2008.

86. WWF Sweden. WWF Kommenterar Skogspropositionen: Regeringen Missar Miljömålet i Skogen. Available Online: http://www.wwf.se/show.php?id=1170111 (accessed on 27 January 2015).

87. Sveaskog. Remissyttrande: Sverige Inför Klimatförändringarna-Hot Och Möjligheter; Sveaskog: Stockholm, Sweden, 2008.

88. Swedish Government. En skogspolitik i Takt Med Tiden; Prop. 2007/08:108; Government Offices of Sweden: Stockholm, Sweden, 2008.

89. Greenpeace Sweden. Press Release: Regeringens Skogsproposition Hotar den Biologiska Mångfalden; Greenpeace Sweden: Stockholm, Sweden, 2008.

90. Jonsson, B.G.; Laikre, L.; Götmark, F.; Ryman, N.; Almered Olsson, G.; Björk, L. Skogspolitiken hotar biologiska mångfalden. Dagens Nyheter, 13 April 2008.

91. Rydell, B.; Nilsson, C.; Alfredsson, C.; Lind, E. Klimatanpassning i Sverige; Nationella plattformen för arbete med naturolyckor, National Platform for Dealing with Natural Disasters: Stockholm, Sweden, 2010.

92. Swedish Forest Agency. Skador på Skog, Skogsskötselserien; Swedish Forest Agency: Jönköping, Sweden, 2009.

93. Eriksson, L.-G. Kompetenssatsning Inom Klimatområdet; Swedish Forest Agency: Stockholm, Sweden, 2009.

94. Swedish Government. En Sammanhållen Klimat-Och Energipolitik—Klimat; Prop. 2008/09:162; Government Offices of Sweden: Stockholm, Sweden, 2009. 
95. Hårsmar, P.-O. Utökad Varningstjänst för Extremväder: Rapport till Regeringen; Swedish Meteorological and Hydrological Institute: Norrköping, Sweden, 2009.

96. SEPA. Grön Infrastruktur: Redovisning av Regeringsuppdrag; Swedish Environmental Protection Agency: Stockholm, Sweden, 2012.

97. Swedish Forest Agency. Swedish Statistical Yearbook of Forestry 2012; Swedish Forest Agency: Stockholm, Sweden, 2012.

98. Swedish Forest Agency. Swedish Statistical Yearbook of Forestry 2013; Swedish Forest Agency: Stockholm, Sweden, 2013.

99. Haas, P.M. Do regimes matter? Epistemic communities and Mediterranean pollution control. Int. Organ. 1989, 43, 377-403.

100. De Koning, J.; Winkel, G.; Sotirov, M.; Blondet, M.; Borras, L.; Ferranti, F.; Geitzenauer, M. Natura 2000 and climate change-Polarisation, uncertainty, and pragmatism in discourses on forest conservation and management in Europe. Environ. Sci. Policy 2014, 39, 129-138.

101. Offermans, A.; Cörvers, R. Learning from the Past; Changing Perspectives on River Management in the Netherlands. Environ. Sci. Policy 2012, 15, 13-22.

102. Winkel, G. Forest conservation policy in a changing climate. For. Policy Econ. 2013, 36, 1-5.

103. Keen, M.; Brown, V.A.; Dyball, R. Social learning: A new approach to environmental management. In Social Learning in Environmental Management: Towards a Sustainable Future; Keen, M., Brown, V.A., Dyball, R., Eds.; Earthscan: London, UK, 2005; pp. 3-21.

104. Fiorino, D.J. Environmental policy as learning: A new view of an old landscape. Public Adm. Rev. 2001, 61, 322-334.

105. Glasbergen, P. Learning to Manage the Environment, in Democracy and the Environment: Problems and Prospects; Lafferty, W.M., Meadowcroft, J., Eds.; Edward Elgar Publishing: Cheltenham, UK, 1996.

106. Swedish Forest Agency. Förstudie om ett Nationellt Skogsprogram för Sverige: Förslag och Ställningstaganden; Swedish Forest Agency: Jönköping, Sweden, 2013.

(C) 2015 by the authors; licensee MDPI, Basel, Switzerland. This article is an open access article distributed under the terms and conditions of the Creative Commons Attribution license (http://creativecommons.org/licenses/by/4.0/). 